\title{
CONVERTIBLE BONDS AND STOCK PURCHASE WARRANTS
}

\author{
A. A. BERLE, JR.
}

A convertible obligation may be defined for the purpose of this study as a corporate obligation to pay money which includes a stipulation granting to the holder at his election the privilege 1 of requiring the debtor corporation to deliver shares of stock in place of payment of the debt. A stock purchase warrant may be defined as a corporate instrument by whose provisions the corporation binds itself to deliver shares of its stock to the holder at his election upon payment to it by the holder of a specified sum of money per share, at or within a time, and on conditions set forth in the instrument. The possessors of convertible obligations and stock purchase warrants may be referred to, where appropriate, as "privilege holders."

Convertible bonds and notes have been familiar documents on the stock exchanges for a number of years. Stock purchase warrants have only recently become fashionable, and their form is not yet fixed. Commonly they are delivered by the corporation at the time of the sale of its bonds or notes, as part consideration for the payment of the purchase price of such obligations. They are frequently, perhaps usually, separable from the bonds; ${ }^{2}$ they are sometimes physically attached in a manner

\footnotetext{
1 The word "privilege" used in connection with conversion and stock purchase warrants, besides being juridically accurate, is the classic phrase on the subject. See the opinion of Field, J., in Hotchliss v. Nat'l Banls, 21 Wall. 354, at 355 (U. S. 1874): "The special agreement as to the serip preferred stock in no degree changes the duty of the company with respect either to the principal or interest stipulated. It confers a privilege upon the holder of the bond, upon its surrender and the surrender of the certificate attached, of obtaining full preferred stock."

2 Occasionally in the past the stock purchase warrant, though nominally separable, was joined to the bond itself. Thus, in perhaps the earliest case of a true stock purchase warrant, Van Allen v. Illinois Central R. R., 7 Bosw. 515 (N. Y. Super. Ct. 1S61) bonds had attached to them serip entitling the holder, on presentation of the bond, to become a stoclsholder in the Illinois Central Railroad, but as such stockholder he was liable for calls for the subscription price of the stock. It is true that it was represented calls would probably never be made on the stockholders. Apparently, however, the scrip had to be presented with the bond itself, though physically separable.

Occasionally the instrument giving the right to convert $a$ bond is separable, but the ability to separate the privilege is illusory, since the bond has to be presented for conversion along with the scrip embodying the agreement giving the privilege of conversion. This was the case in Hotchkiss v. Nat'l Banks, supra note 1 . Today, the conversion privilege is usually embodied in the bond itself. A stock purchase warrant is usually a sep-
} 
permitting separation, or they may be wholly distinct instruments delivered simultaneously with the bonds or notes, or they may be entirely independent instruments not connected with obligations for the payment of money. They are frequently delivered to banking houses of issue and retained by such houses as a part of their compensation for undertaking flotation of an issue of security. They are commonly bought and sold in the open market. Their only invariable features are covenants on the part of the issuing corporation to deliver stock upon payment of a stated price (which may vary depending on the time when the holder exercises his privilege, or on the number of shares which have been issued to holders for their warrants at the time of exercise) and covenants defining and limiting the time or times, or period of time, as the case may be, at or within which the privilege may be exercised. It is perhaps apposite to examine their exact status, not without a certain wonder at the sudden popularity of a form of financing whose incidents are so little known.

\section{OF THE NATURE OF CONVERTIBLE OBLIGATIONS AND STOCK PURCHASE WARRANTS}

The privilege granted to the holder of a convertible obligation to require stock at his election instead of money in payment of the debt evidenced by the instrument, is an option. ${ }^{3}$ Both as a matter of law and of common sense, this conception seems well-founded. The privilege and the covenants creating it are no part of the corporate obligation to pay money; they are separable from the promise to pay; their invalidity will not affect it. ${ }^{4}$

The stock purchase warrant is likewise an option, ${ }^{5}$ and follows in large measure the rules relating to convertible obligations.

arate instrument, physically detachable from the obligation to pay money and exercisable without presentation of the obligation.

${ }^{3}$ See Pratt v. American Bell Telephone Co., 141 Mass. 225, 5 N. E. 307 (1886) ; John Hancock Mutual Life Ins. Co. v. Worcester R. R., 149 Mass. 214, 21 N. E. 364 (1889) ; Day v. Worcester R. R., 151 Mass. 302, 23 N. E. 824 (1890); Chaffee v. Middlesex R. R., 146 Mass. 224, 17 N. E. 316 (1888) ; Gay v. Burgess Mills, 30 R. I. 231, 74 Atl. 714 (1909); Wall v. Utah Copper Co., 70 N. J. Eq. 17, 62 Atl. 533 (1905); Belmont v. Erie R. R., 52 Barb. 637 (N. Y. Sup. Ct. 1869).

4 Parkinson v. West End Ry., 173 Mass. 446, 53 N. E. 891 (1899); Hotchkiss v. Nat'l Banks, supra note 1. Further, where the obligation to pay money is extended, nothing being said about the conversion privilege, the extension does not apply to the conversion privilege. See Muhlenberg v. Philadelphia \& Reading R. R., 47 Pa. St. 16 (1864). There a convertible bond matured on July 1, 1860. Conversion was allowed up to date of maturity. An agreement was entered into extending the maturity of the loan. Held, that this did not extend the conversion date measured by the original maturity.

$\checkmark$ Van Allen v. Illinois Central R. R., supra note 2. 
But it has peculiar problems of its own. The question of consideration does not ordinarily arise in the case of a convertible obligation; the covenant of conversion and the covenant to pay money are both supported by the payment of cash to or for account of the debtor corporation. The stock purchase warrant, however, may be issued by the corporation for no apparent consideration whatever. Although such instruments are commonly transferred in connection with the issue of obligations, the consideration of the obligation is plainly the payment of money for ${ }^{1}{ }^{6}{ }^{6}$ and the separability of the warrant may militate against the idea that the purchase price of the obligation includes also a payment for the privilege contained in the warrant. Neither a convertible obligation nor a stock purchase warrant, as such, gives the holder an equitable right in shares of stock.: Such instruments create no trust in respect of any reserved shares; nor do they place the holder in a position to enforce any of the rights of a shareholder. All of the incidents of the situation must be worked out on simple lines of contract.

One question peculiar to stock purchase warrants deserves a word. At present these documents are commonly made in favor of "bearer" and pass from hand to hand. They are regarded as negotiable. They are not covered by the provisions of the uniform stock transfer act; and they have no body of custom hardening into law such as protects stock certificates. Their negotiability remains to be established. ${ }^{\mathrm{s}}$ Unlike the privilege of

6 In at least one case the question of consideration was seriously raised, though the court found it possible to decide without passing on the point. Welles v. Chicago \& N. W. Ry., 163 Fed. 330 (C. C. E. D. N. Y. 100S) in which the plaintiff was the legatee of the original purchaser of the convertible bond. After holding that the conversion privilege was distinct from the obligation to pay money, the court found it unnecessary to pass on the question whether or not this obligation in the hands of the plaintiff had been acquired for consideration, passing to the railroad, since the conversion right was denied on other grounds.

7 Parkinson v. West End Ry., supra note 4; Pratt v. American Bell Telephone Co., supra note 3.

$s$ The early cases rather plainly intimate that instruments containing the conversion privilege and stock purchase warrants are not negotiable and cannot become so. Thus, in Hotchliss v. Nat'l Banks, oupra note 1, it was remarked that the obligation to pay was negotiable, but that this did not necessarily extend to the attached scrip agreement permitting conversion; in Van Allen v. Mlinois Central R. R., supra note 2, the holder of the right to subscribe was treated as an assignee; in Welch v. Sage, $47 \mathrm{~N}$. Y. 143 (1872) upon the same state of facts as in Hotchliss v. Nat'l Banlss (where a bond having a detachable scrip promise to convert the bond into stock was stolen, the scrip promise removed and the bond pledged with a bank) it was held that the rules governing negotiability of the bond would apply to protect the pledgee of the stolen bond, despite the fact that the scrip itself was not negotiable. See also Lisman v. Mrilwaukee, L. S. \& W. R. R., 161 Fed. 472 (C. C. E. D. Wis. 1908), aff'd 170 Fed. 1020 (C. C. A. जth, 1909), certiorari denied, 214 U. S. 520, 29 Sup. Ct. 700 (1909). 
conversion contained in an obligation to pay money which passes with the obligation itself as an incident thereof, the stock purchase warrant must stand upon its own terms. It is believed, however, that negotiability to the extent permitted to stock certificates will be worked out on the simple ground that an instrument of naked promise running to bearer contemplates assignment, and both by actual intent and verbal implication imports (1) consent on the part of the issuing company that such assignment may be made and (2) an agreement to honor the assignment when made. Since the form of assignment is the same as that appearing upon a stock certificate, and upon the familiar documents granting a stockholder the right to subscribe -perhaps the closest approximation to the stock purchase warrant known prior to the appearance of the latter instrument-an intention may be presumed (and the presumption will be based on an overwhelming probability in fact) that the same effect was contemplated. Further, the privilege, whether of conversion or of purchase, is almost invariably expressed in terms of an offer of a unilateral contract. A person fulfilling certain conditions. leaps into the position of obligee under the contract. ${ }^{\circ}$ The conditions are that he possess a particular instrument; that he present it at a stated time and place; that he tender either an obligation for cancellation, or a stated sum of money. These are the essential terms of the offer; and it is not material to the discussion to determine how the person fulfilling the conditions became able to do so.10 For purposes of market transaction, the result would be a practical negotiability.

Three points of view are important in considering the type of security under discussion: (1) that of the holder of the privilege; (2) that of the stockholders in the issuing corporation; and (3)

Despite this adverse authority, courts can hardly be blind to the fact. that a new commercial instrument is appearing, concerning which a custom of merchants has already grown up.

0 This unilateral quality appears in a number of instances and is perhaps the best recognized incident of a conversion privilege, and the same result will probably follow in connection with stock purchase warrants. See, for example, Carpenter v. Chicago, M. \& S. P. Ry., 119 App. Div. 169, 171, 104 N. Y. Supp. 152, 153 (1st Dept. 1907) where McLaughlin, J., said: "What the defendant agreed to do was to pay the bonds on the first of July, 1905, or to accept them before that date in payment of preferred stock, providing certain conditions specified were complied with." To the same effect is Loomis v. Chicago, M. \& S. P. Ry., 102 Fed. 233 (C. C. A. 2d, 1900); Van Allen v. Illinois Central R. R., supra note 2, in which the right to subscribe was considered as an option, providing certain specific conditions were complied with.

10 The text discussion assumes the usual form of a convertible bond or stock purchase warrant, in which upon fulfilling certain conditions the privilege holder becomes immediately entitled to receive stock. It is, of course, possible to conceive of an option to enter into a bilateral contract, as, for instance, to purchase stock on the installment plan.

The nature of an option requires a word. The writer has here followed 
that of the corporation itself. The three diverging views form the outline of the ensuing discussion.

OF HOLDERS OF CONVERTIELE OELIGATIONS AND STOCK PURCHASE WARRANTS

The motive leading investors to acquire convertible obligations and stock purchase warrants is the desire to secure an opportunity to participate in the business of the issuing corporation for a fixed price. The bargain the investor usually thinls he is making is that he will acquire stock bearing the privileges which stock of the same class has at the time he purchases the corporate obligation, but which, over a period of time, will have proved very valuable. This is a misconception. Corporations are not static; they retrogress or move forward, their capital structure changes, and the share of stock of today, while legally an identical unit with the share of tomorrow, commercially may have become entirely different.

For purposes of illustration we may take a convertible note to pay $\$ 1,000$ with a privilege in the holder to demand in lieu thereof ten shares of stock of the par value of $\$ 100$ each. The same consideration will be applicable to the holder of a stock purchase warrant entitling the holder to purchase 10 shares of such stock at $\$ 100$ each. Let it be assumed that the shares are of common stock, and that the corporation has only one class of shares outstanding. All of the earnings of the corporation inure to the benefit of this class of stock. Assume further that the corporation has a large surplus already accumulated forming a part of the book value of this stock, when the warrants or convertible obligations are issued; and that the privilege of conversion or of purchase does not come into effect for a period of two years. Within that time the corporation may have distributed its entire surplus as dividends; or may have created an issue of preferred stock placing the common stock in a highly unattractive position both as to assets and dividends; or it may have reduced the par value of its shares; or it may have divided them into many shares of a less par value; or may have made them over into non-par shares; or may have issued additional shares of the same class; or may have paid stock dividends; or have merged, consolidated, or even dissolved. In short, the en-

the theory that an option consists of two distinct elements: (a) an offer to contract, which, in the case of convertible obligations and stocls purchase warrants, is commonly a unilateral offer, and (b) an agreement not to revoke such offer. Obviously, the rights of the privilege holder prior to the exercise of his privilege arise under the second characteristic of the option. After its exercise he may be enforcing the obligation of the corporation under either or both characteristics. 
tire capital structure of the concern may have been radically altered; with or without changing the nature or ending the existence of the shares themselves. Any one of these steps may be fatal to the hopes of the privilege holder. What rights, if any, has he?

He has in any event a right to require the obligor corporation to maintain the integrity of the shares, - that is to say, to maintain the shares as the same or equivalent units of contribution of capital-in respect of which the privilege is granted, in such manner as will permit the corporation to fulfill its obligation.

The holder of a privilege to acquire shares enforceable upon election is in no sense a stockholder.11 Any rights he has must be derived from his contract. At law this right is single and simple: at the time of election, if the corporation is not in a position to deliver stock to him, he may recover as damages the difference between the market value of the stock he is entitled to require at the time of election, and the cost of the stock at the conversion or option rate. ${ }^{12}$ This rule, worked out originally in cases where the corporation was in a position to deliver stock but refused to do so, has never been altered. Plainly this remedy is inadequate to cover such elusive organisms as shares of stock. The market value, the ability of the corporation to deliver, the very existence and identity of the thing depends too much on the will of the corporate management. Unless the privilege of conversion or purchase is guarded in some more fundamental way it can be rendered nugatory.

In an early case the courts faced a situation in which the obligor corporation had consolidated with another, changing its name and powers, and the consolidated corporation's shares wer'e distributed to the stockholders of both of the consolidating corporations upon a plane of absolute parity with the old stock. Mr. Justice Holmes was able to spell out a continuation of the corporate entity under the guise of the consolidated corporation, and he enforced the privilege of conversion by requiring delivery of stock in the new corporation. ${ }^{13}$ Where, again, a corporation issued convertible bonds entitling the holder to exact 10 shares of the corporation's capital stock with a par value of $\$ 100$ per share for each $\$ 1,000$ of principal obligation, and the corporation changed its authorized stock from $\$ 100$ par value to $\$ 1.00$ par value, it was recognized on all sides and a decree entered, that the privilege holder might demand stock having a par value of $\$ 1,000$ for each $\$ 1,000$ of obligation-that is, that his conver-

\footnotetext{
11 Gay v. Burgess Mills, supra note 3; Chaffee v. Middlesex R. R., supra note 3.

12 See Lisman v. Milwaukee, L. S. \& W. Ry., supra note 8; Chaffee v. Middlesex R. R., supra note 3.

13 Chaffee v. Middlesex R. R., supra note 3.
} 
sion right permitted him to exact the equivalent par value of stock, though the number of shares constituting it had been altered.14 Looking through the bare form of the stock certificate the court perceived an obligation to deliver a fixed unit of capital and decreed performance upon that basis.

Many covenants in support of conversion or stock purchase warrants explicitly state this rule at present. Particularly where the privilege may be exercised in respect of stock without nominal or par value - in which case the shares may be split with great ease so that the units covered by the privilege have actually been diminished in value, thereby impairing their integrity, though nominally they appear the same-it is frequently provided that the conversion privilege may be exercised in respect of a greater number of shares in the event of any splitting of units. It is believed that these specific covenants merely state the rule which a court of equity would enforce in any event. The fact that the conversion privilege uses a name which is applicable to the shares both before and after the splitting-up process, can hardly be construed to give the obligor corporation liberty to evade its promise by completely altering the unit value of the share.

Where this unit of capital is measured by par value, the problem is simple enough. The privilege holder is entitled to receive stock of or aggregating the par value of the stock stipulated to be delivered to him on the exercise of his privilege. Where, however, the stock is non-par, the problem becomes difficult to state, though not logically distinguishable in kind." Each share of non-par stock has a capital value, measured by the consideration dedicated to capital, paid for the share. It is true that new shares may be issued for a less consideration, thereby affecting the capital value of all outstanding shares. If, however, addirional non-par shares represent additional contributions to capital approximately equal to the capital value at the time of issue of the then outstanding shares, the relative values of units are preserved, though the actual amount of capital contribution may have varied. The varying price at which new shares of non-par stock can be issued should, if their consideration is equitably fixed, merely reflect the fortunes of war of the corporation and the corresponding fluctuations in value of its outstanding. shares.

But where new non-par shares are issued for a consideration

I4 Gay v. Burgess Mills, supra note 3; John Hancock MIutual Life Ins. Co. v. Worcester Ry., supra note 3.

${ }^{25}$ See, for a good example of very specific covenants granting to holders of convertible bonds the right to participate in split units of non-par stocls, the trust indenture securing the issue of Cuba Cane Sugar Company Conrertible $7 \%$ Gold Bonds. 
which does not reflect an equitable contribution to the corporate resources, so that the new shares derive an undue advantage over the old, (as it were, levying tribute on them) what has occurred is not an increase of the number of capital units, but a partial splitting of the units. Mathematically this will occur whenever non-par stock is issued at a price lower than the book value of the non-par shares already outstanding. ${ }^{10}$ The mathematical test is too rigid practically, and the test should be whether or not the new shares have been issued for a fair price based on the existing market for such stock.

In case there has actually been not an addition of a number of new units bearing approximately an equal burden, but the splitting of the old units into a number of fractions, the rule of the Rhode Island court in respect of par stock should be applied to non-par shares, and the privilege should be applied to a sufficient number of the new units as will, in the aggregate, place the privilege holder in the same position he would have held had the old units been preserved. And this should be the rule whether in equity or at law; for the damages at law will then be based not on the strict number of shares described in the privilege, but upon the market value of the number of shares of old units had they been maintained intact.

Surplus is quite another matter. The privilege of conversion or purchase, as has been seen, binds the corporation's hands as regards distribution of its capital; but there is no equivalent rule as to surplus. Suppose at the time of issuing a stock purchase warrant or a convertible note, the stock has a given right in capital, and a pro rata share of surplus attributable to it. It is well settled, and rightly so, that the corporation may, if it chooses, strip its surplus account bare, distributing it fully to the stockholders without considering the effect on the value of the shares in respect of which the privilege might operate. ${ }^{17}$ If

${ }^{16}$ For a discussion of the price at which non-par stock may be issued, and the theory that where issued for an unduly low price, such stock lovies tribute on all other stock of the same class, thereby effecting the splitting of capital, see Berle, Problems of Non-Par Stock (1925) 25 CoL. L. Rev. 43, 56. The problem has recently been under very close and careful review in the case of Hodgman v. Atlantic Refining Co., 300 Fed. 590 (D. Del. 1924) rev'd, 13 Fed. (2d) 781 (C. C. A. 3d, 1926). The rule adopted by both the District Court and the Circuit Court of Appeals in this litigation was the same; but the Circuit Court of Appeals found peculiar facts to exist, justifying impairment of the capital units, as this seemed to bo necessary to provide funds for the corporation.

${ }^{17}$ Pratt v. American Bell Telephone Co., supra note 3 (issue of new stock impairing accumulated surplus); Sutliff v. Cleveland \& Mahoning R. R., 24 Ohio, 147 (1873) (distribution of surplus by way of stock dividend).

The extreme application of this rule occurred in the case of Gay v. Burgess Mills, supra note 3. There the directors declared a dividend of 
the privilege holder wishes to participate in the distribution he must elect to become a stockholder and convert his obligation, or pay for his stock. Up to the last moment of election, he is not accorded any of the rights of a stockholder. This is good sense as well as good law. It rests upon the actual intent of the parties, whether expressed or tacit. The surplus of a corporation is not only subject to distribution, but the distribution of it, or at least a portion of it, is the very objective which leads investors to become stockholders. Receipt of dividends is perhaps the prime desire of every stockholder. The privilege holder knows this. He certainly is in no position to quarrel if the corporation makes distribution, whether by way of cash dividend or stock dividend; there is no obligation resting on the corporation to maintain any surplus fund for the benefit of the privilege holders. ${ }^{18}$

$50 \%$, payable $10 \%$ annually during 5 years, but payable only to stoclholders of record on the date of declaration. This stripped the corporation absolutely bare of surplus account. Thereafter, the holder of a convertible bond exercised his conversion privilege and demanded to be allowed to share in the dividend declared, though his stocl: was acquired subsequent to the record date. The Rhode Island court held that he was not entitled to participate.

It may be asked, what, then, is the value of the privilege of conversion or purchase? Obviously, the principal hope of increase in value of a share of stock is the piling up of surplus behind it, a surplus in which the shares of stock optioned to the privilege holder would participate. As has been seen, there is no reason why this surplus should be maintained for the benefit of the privilege holder.

Valuation of the privilege is perhaps rather for the banlier than the lawyer to estimate. Yet the answer seems plain. Over a period of time the enterprise in question may have demonstrated an earning capacity. Although no surplus is piled up, the value of a share with a demonstrated earning capacity, is far greater than the value of a share without. MIaniIestly, for the interests of the stockholders, strategy would seem to dictate that the corporation declare out all its surplus as dividends prior to the arrival of the conversion or option date; or, if it needs worling capital, capitalize such surplus and declare a stock dividend. This rould prevent privilege holders from sharing in surplus. Yet the fact that the enterprise could earn a respectable surplus would give value to the optioned shares, making exercise of the privilege worth-while. Stock purchase warrants are too new to have reached the stage when corporations endearor to wrestle with the possibility of avoiding a distribution of the profits of past years to privilege holders who elect to demand stock.

is As soon, however, as such privilege holder has exercised his privilege, the situation changes at once. He becomes a stocliholder, and any discrimination against him will be prevented by the courts. Thus, in Jones v. Terre Haute \& Richmond R. R., 57 N. Y. 196 (1874) a conversion pritilege was exercised by mail on November 26 and stock actually issued on December 3. On December 17 the directors declared a cash dividend and a stock dividend to stockholders of record on November 30, payable January 1. The plaintiff brought an action for both dividends. The corporation defended on the ground that he was not a stockholder of record on November 30. The New York Court of Appeals held that he was entitled to both 
Similar considerations govern the financial structure of the enterprise in other matters. If the privilege is granted in respect. of common stock at a time when the corporation has no other stock outstanding, and it later chooses to load its capital structure with a burdensome issue of preferred stock having priority both as to assets and as to dividends, the position of the common stock in respect of which the privilege was granted, may become far less valuable than was the case when the privilege holder purchased his warrant or his convertible obligation. It seems, however, that he has no right to complain. True, no additional issue of stock may be created which will absorb to itself any part of the capital contribution in respect of the original shares. Should it do so we should have the phenomenon of splitting of units, and the rule applicable to preservation of capital integrity would at once come into play. Where this is not the case, the privilege holder finds himself in exactly the same position as the other holders of the class of stock in respect of which his privilege was granted; and the value of his privilege shares the fortunes of war with the value of other stock.

\section{OF THE POSITION OF THE STOCKHOLDERS IN CORPORATIONS CREATING PRIVILEGES OF CONVERSION OR PURCHASE}

The position of the holder of outstanding shares of a corporation which has or is about to create privileges of conversion or purchase is precisely the same in respect of the instruments carrying such privilege as it is in connection with the issue of shares of stock in respect of which the privilege is granted.

These rights are, on the whole, plainly defined. Where par stock is concerned, new shares having par value must be issued for not less than par. ${ }^{29}$ Where his own and new shares are without par value, his right is that his pro rata share in the corporate assets shall not be diminished unreasonably by the new issue. The law on this subject is crystallizing into a rule that new non-par shares must be issued within reasonable range of the best obtainable price. ${ }^{20}$

He has also a pro rata share of control based upon the proportion of votes which his shares can exercise in ratio to the total amount of authorized shares. This right together with his right in accumulated surplus, if any, is protected by granting to

dividends, since the directors were not entitled by antedating the record date, to prevent the privilege holder from sharing in the general distribution.

${ }^{19}$ Carver v. Southern Iron \& Steel Co., 78 N. J. Eq. 81, 78 Atl. 240 (1910) (a careful examination of the subject by Garrison, V. C.).

${ }^{20}$ See supra note 16. 
him a privilege of preempting, in proportion to the number of shares held by him, any newly created issue of stock to be sold for cash. ${ }^{21}$

All of the foregoing stockholder's' rights exist where privilege of conversion or purchase is granted by the corporation. It is thus settled that securities convertible into stock having par value may not be issued at a price materially less than par, and that conversion must take place at a rate which will be equivalent to payment of the par value of the stock to be received. As to non-par shares, the question appears never to have been passed upon; but it is hardly conceivable that the courts would not afford a stockholder a remedy by way of injunction were the conversion or option price fixed at a rate which would impair the capital value of the outstanding shares. There is, however, a peculiar problem incident to the fluctuating price at which nonpar stock can be issued. Since the value of a non-par share is the aliquot portion of the corporate assets attributable to such share, and since this value at a given time cannot be prophesied in advance, the rate at which conversion or purchase may take place fixed in the convertible obligation or warrant, while just at the time of the issue of such instruments, may be grossly unfair when the time for the exercise of the privilege arrives.:

It is believed, however, that the stockholder is sufficiently protected if the conversion rate or purchase price is fixed at a rate ascertainably fair at the time the privilege is created. The increased value of the stock, so far as the mathematics of the

21 The double reason for the right of preemption-preservation of proportionate voting control and preservation of proportionate property interest-is well stated in Crosby v. Stratton, 17 Colo. App. 212, 220, 08 Pac. 130 (1902). The cases are collected in 14 C. J. 394, note 37 . See particularly Stokes v. Continental Trust Co., 186 N. Y. 285,78 N. E. 1090 (1906).

22 There is a difference between the rules governing issue of non-par shares and par shares.

Eolders of par shares agree, or at least understand and contemplate, that new issues of stock may take place at par, though mathematically this might reduce the value of the outstanding par shares because of dilution of surplus. In such case the stockholder is protected in some measure by his preemptive right. There is authority (Stokes v. Continental Trust Co., supra note 21) to the effect that par shares may be issued at a higher price; and it is true that some public utilities commissions require public service companies to issue their stock at more than par, but this is based not on corporation law but on the requirement that a public service corporation secure additional capital as economically as possible.

Non-par shares, however, apparently must be issued for a price which will be fair to existing stockholders, whatever may have been their original capital contributions. Accordingly, in a convertible issue it is always permissible to name par or better as a conversion price in respect of par shares, since new par shares can always be issued at par. It is never possible, however, to forecast accurately the price at which non-par shares could be issued at a future time. 
situation is concerned, must depend on the piling up of a surplus account. As has been seen, the corporation is in a position to distribute this, thereby protecting the stockholder. Since the stockholders themselves must (as will be seen) authorize the creation of the privilege, they will have assented to the possibility envisaged. Still more important, they are protected by preemption rights.

Preemption in respect of newly created shares of stock rests on judicial rather than statutory law. Directed originally toward preserving to stockholders their aliquot control, it has become an instrument of even more importance for the purpose of maintaining stockholders' rights in surplus. Grants of a privilege of conversion or purchase present exactly the same threat both as to control and rights in accumulated surplus (though in the latter case the threat is weaker) as do newly created shares of stock. ${ }^{23}$ It has accordingly been settled, and careful corporation lawyers recognize, that convertible obligntions and stock purchase warrants must be first offered preemptively to the existing shareholders of the corporation, to the same degree that the shares of stock in respect of which the privilege is granted must be offered. Shareholders can enjoin the issue of such privilege unless and until they are granted such preemption right. Probably in respect of convertible obligations, the corporation has not even the historic method of eluding its obligation by the issue of obligations for property. It

${ }^{23}$ For a very careful examination of the rights of a stockholder when an issue of bonds convertible into stock of the same class is created, see Wall v. Utah Copper Co., supra note 3, per Pitney, V. C.

The rights of the stockholder with respect to an issue of convertible bonds or stock purchase warrants are strictly limited to the rights he would have with respect to the option as to stock. It is entirely conceivable that ho may have no preemption rights whatever-as, where the optioned stock has already been offered to the stockholders and declined or where the stock is authorized and unissued but not newly created.

A different and very intricate situation may arise after the issuo of the convertible obligation or warrant. At the time when this obligation is offered; shares may be reserved to take care of conversion or purchase warrants, which are not subject to preemption. These may be disposed of and an attempt made to create a new issue, to be held for the privilege holders. The obligations being already offered, it is impossible to offer them pro rata to shareholders. The impasse is complete. The newly created issue may be preempted by shareholders if they so desire; and the corporation will have no stock to deliver to the privilege holders, laying itself open to an action in damages.

As a practical matter, the corporation can authorize so large an issuo of new shares that its existing shareholders will not take them up, and thereby place itself in a position to redeem its obligations, but this is manipulation and not law.

Statutes not infrequently affect preemptive rights. In New York it is an open question whether there is a preemptive right in connection with convertible bonds. See Cons. Laws (Cahill, 1923) c. $60, \S 16$. 
can issue shares for property without granting a preemptive right-though the logic of this has never been satisfactorily developed. It can issue promises to pay in return for property; but a conversion privilege attached to such an obligation will not mean that the stock issued on the exercise of the conversion right is issued for property. The stock is issued for cash, the cash being applied to the liquidation of the obligation to pay. It would seem, therefore, that the preemptive right applies in practically every case where convertible obligations are issued, provided that the stock in respect of which such privilege can be exercised, would itself be subject to such preemption.

\section{OF THE POSITION OF THE CORPORATION}

The position of the corporation is largely delimited by the foregoing discussion. Its liability, however, is distinct. It is a mechanism through which all of the rights, both of privilege holders and shareholders, must be worked out; and a violation of any of their rights will react almost exclusively upon the corporation itself. It is, in a sense, the stakeholder. Some of its specific liabilities may be listed:

(1) It must be in a position to deliver the stock in respect of which a privilege of conversion or purchase is granted, at the time when such privilege is exercised. While apparently it need not keep such stock on hand continuously, nevertheless when the day comes it must deliver; or become liable in damages.

(2) It must so manage its corporate affairs that the integrity or equivalence of capital contribution of the unit, to be delivered upon exercise of the privilege, has not been impaired. Should it fail to do so, there is a liability in damages and properly, for the situation permits of an equitable liability to deliver existing units which will place the privilege holder in the position he would have been in had the agreed units been delivered.

(3) It must, on creation of a privilege of conversion or purchase, offer to its existing shareholder's a preemptive right to the extent that such shareholders will have such right in respect of the stock to be delivered on the exercise of the privilege. Failure to observe this obligation will afford ground for injunctive relief; or if the process has gone too far to permit aid by injunction, the shareholders can sue the management for ensuing damages.

(4) It must. fix the price at which the privilege can be exercised at not less than par in respect of par shares, or at not less than a fair price at the time of creation in respect of non-par shares, regard being had to the equitable rules governing the price at which new non-par shares may be offered. Here again 
the stockholders may be permitted injunctive relief, or they may hold the management liable for such damages as can be established where the obligation is disregarded.

(5) It is subject to such specific restrictions in respect of privileges of conversion or purchase created by it, as are contained in its agreement with such privilege holders.

Must the corporation stay in existence? Mr. Justice Holmes has answered this in the negative, ${ }^{24}$ remarking that "if the corporation which made the bond finds it for its interest to go out of existence at or before the maturity of the obligation, the option given to the bondholder will not stand in the way." So far as mere dissolution of the corporation is concerned, this is apparently the rule today. ${ }^{25}$ It is believed, however, that the brutal statement of Holmes, J., is far too broad to cover the present circumstances. Were the process merely a formal one-dissolution in one state and reincorporation in another-though the legal identity be changed, the commercial identity is so far the same that it would seem mere fraud to deprive the privilege holder of his right. Even Mr. Justice Holmes' statement would not cut off the holder's right to damages-a liability which would survive even the dissolution of the corporation, since the corporate entity is invariably preserved for the purpose of fulfilling its contract obligations. Probably the corporation may terminate its activities and its existence, and there being no enterprise in which to share, the subject matter of the option has passed out of existence and the contract itself falls thereby, just as an option given by $X$ to sell to $Y$ his yacht ceases to be effective if the yacht sinks. But where the enterprise has merely changed its legal clothes, an entirely different picture is presented. The liability of the dying corporation can be charged in

24 Parkinson v. West End Ry., supra note 4, at 448, 53 N. E. at 892 .

25 In Lisman v. Milwaukee, L. S. \& W. Ry., supra note 8 , the holder of bonds convertible into stock of the defendant, demanded conversion long after the defendant had consolidated with the Chicago, Milwaukee \& St. Paul Railroad. Conversion was allowed within ten days after a dividend date; since consolidation had taken place, no dividends had been declared, the stock being dead. Held, that the privilege holder was bound to anticipate the vicissitudes of the corporation, including change of ownership; and his conversion privilege was thus wiped out. To same effect, see Taggart and Bennett v. Northern Central Ry., 29 Md. 557 (1868) (where, however, there was an element of estoppel, because the privilege holder who had also been a stockholder voted to approve the consolidation); Welles v. Chicago \& N. W. Ry., supra note 6; Rosenkrans v. Lafayette, B. \& M. R. R., 18 Fed. 513 (C. C. D. Ind. 1883).

How far these cases of legislative consolidation could be held to apply to the less drastic industrial reorganizations of today may be fairly disputed. Certainly, if the only object of reorganization were to cut off the conversion privilege, it would seem that equity would afford a remedy. The "traceable identity" rule stated in the text above seems a possible line of approach to an equitable solution. 
equity against the assets of the nascent one; every element of fraud is present.

Reorganization may, however, be far more complex. By entering a combination, as, a consolidation of many units, the enterprise may have so changed its character that its identity will have been lost, though the substance of it continues compounded with different elements. Relief in such cases must turn upon the circumstances involved; only a general line of attack can be suggested. Where the process approximates extinction of the enterprise, the privilege should fall. Where, however, its form has merely been changed so that the share units of the old enterprise are traceable with relative clarity into share units of the new enterprise, it is submitted that equity should afford relief. This might be by requiring delivery of the new share units; or if that is impossible, by requiring the consolidated corporation to shoulder a liability in damages based upon the difference between the price which the privilege holder would have paid for the old shares and the value so far as ascertainable of the equivalent units into which those shares have been transmuted. This implies a modification of MIr. Justice Holmes' decision. The reason is not far to seek. Corporate procedure has become far more fluid since the days when corporations (as was the case with those he had under consideration) were chartered by special legislative act. Today the corporate form of organization lies almost wholly in the choice of the men in charge of the enterprise. The commercial, not the legal, entity controls the situation. Obligations to deliver stock, despite their peculiar incidents, are no less sacred than obligations to pay money. Particularly where stock purchase warrants are concerned, the value of such promises passes currently. The equity of a convertible bondholder of 1899 was not so strong as to lead courts to be astute to safeguard the conversion privilege. The equity of a holder of an open market warrant of today should command the power of a court of equity even to follow an enterprise into a reorganization changing its legal entity, for the purpose of ascertaining, wherever possible, whether the corporate promise can be enforced; and if it cannot be fulfilled in kind, of awarding monetary recovery which will make good the loss of the privilege holder.

The other question which will persistently face the corporation is connected with proper authorization and corporate action in connection with the creation of the privilege. It may validly bind itself by issuing an appropriate convertible obligation or warrant to deliver shares, even though the shares are unauthorized and uncreated. This situation has come under 
judicial scrutiny on various occasions..$^{20}$ That the contract binds the corporation has never been questioned. The improvidence of such a situation from the corporation's point of view is obvious. It may, of course, place itself in a position to fulfill its terms by subsequent corporate action, and if its stockholders are complaisant, no harm is done. Until some privilege holder demands his stock at the appointed time, however dangerous the corporate situation may be, the privilege holder is not in a position to object. Should the corporate stockholders refuse to authorize the additional issue of stock, specific performance will not be granted. ${ }^{27}$ The grounds have been variously stated; one of them being that there is an adequate remedy at law through money damages. Probably the more substantial reason is that a court of equity is not in a position to compel the necessary stockholders' vote authorizing creation of new stock. ${ }^{28}$ In one case it was held that the mere authorization of the convertible obligation imported a creation of the additional stock; but that decision turned on the peculiar situation involved. ${ }^{29}$ Until the day of reckoning comes, the corporation may regard itself free; at that time it must deliver shares if it have them; otherwise, respond in damages..$^{30}$

Its freedom in respect to surplus and to changes in its capital structure, such as creation of stock having a priority over the shares in respect of which the privilege is granted, has already been noted. It is submitted the same freedom exists where it

26 Wood v. Whelen, 93 Ill. 153 (1879) ; Welles v. Chicago \& N. W. Ry., supra note 6 . In Belmont v. Erie R. R., supra note 3 , at $671-673$, the endeavor was to enjoin an issue of convertible bonds on the ground that the corporation had not authorized the stock into which such bonds could be converted. Cardozo, J., discovered in the corporate charter and legislation an authorization to the directors to issue convertible bonds. From this he deduced that the directors without more had authority to create the stock if, as and when necessary, for conversion purposes. To the same effect is Ramsey v. Erie R. R., 38 How. Pr. 193 (N. Y. Sup. Ct. 1869). It must, however, be remembered that the litigation affecting the Erie Railroad in the late 60's was not an academic affair. In one of these cases, the court threatened to dismiss the whole proceeding on the ground that the press and other outside agencies had so interfered with the conduct of the case on the part of the persons attacking the Erie management as to justify an equitable discretion in denying relief.

In New Jersey there is an odd statutory provision permitting the board of directors to authorize shares in respect of which convertible obligations have been issued. See N. J. Laws 1902, c. 5, § 3.

${ }^{27}$ Parkinson v. West End Ry., supra note 4.

28 Lisman v. Milwaukee, L. S. \& W. Ry., supra note 8; Rosenkrans v. Lafayette, B. \& M. R. R., supra note 25 (a very unsatisfactory decision, holding that inasmuch as the shares were no longer in existence, the right of the bondholder was unclear, and no relief would be granted. A consolidation had intervened, complicating the question).

29 Belmont v. Erie R. R., supra note 3.

${ }^{30}$ Van Allen v. Illinois Central R. R., supra note 2. 
chooses to create participating preferred stock sharing in the earnings otherwise attributable to the conversion shares. Just as it may increase the number of its shares, preserving merely the integrity of each as bearing an equal contribution to the corporate capital, and thereby dividing the corporate income among the increased number of units, so it may create other units not altogether on a parity, yet sharing in the total income. Probably it may, within limits, even alter the characteristics of the shares themselves, but such changes must not be so fundamental as to change their identity, or their essential rights. The question is at once raised, what is an essential right. The answer must rest on analogy, since the question has not been squarely presented. Miost charters are subject to amendment and alteration; and under them stockholder's' rights can be altered. As regards preferred stock, it has been held that certain alterations do not affect the essential rights of the holders; others, however, impair the fundamental contract upon which the preferred shares were issued.si Broadly speaking, any change of right as to corporate procedure is not essential; any alteration affecting the property value of the share, or its voting right, so far affects its identity and worth that it cannot be made without the consent of the holder. The privilege holder is entitled to demand that the stock tendered him shall be essentially identical with the stock as it stood at the time the privilege was granted. It will be a question in each case whether or not this identity has been impaired, yet following the rule in Kent v. Quicksilver Mining Company ${ }^{32}$ and the allied cases, it should be no more difficult for courts to establish whether or not there has been such impairment than in any other case where the corporate charter is amended.

Authorization necessary to create a privilege rests in many jurisdictions on statutory provisions. Not infrequently corporation acts require a particular consent of stockholders for creation of a convertible issue. It cannot, however, be assumed that such consent implies also a creation of the stock to be delivered in fulfillment of the privilege. ${ }^{33}$ There are two distinct

${ }^{31}$ Kent v. Quicksilver Mining Co., 78 N. Y. 159 (1879).

32 Supra note 31.

33 It is true that in the Erie Railroad cases authorization to directors to create convertible bonds was considered authorization to create stocli. Wiost statutes today guard the creation of stock far more carefully than was the situation in those cases. Creation of additional authorized stock involves an amendment to the corporate charter under modern practice, maling requisite at least nominal state action in filing a certificate. Action by the board of directors, even if ratified by stockholders, would hardly operate to amend the charter; and any attempt to secure state approval of such action would fall, unless the appropriate agency of the state could be shown direct statutory authority for amendment in this manner. 
processes: authorization of the privilege, and creation of the stock. The latter must depend upon the rules governing the creation of stock exactly as though it were disconnected with any privilege.

It is sufficiently obvious that the practice of issuing convertible obligations and stock purchase warrants is still in its infancy. It is equally obvious that the somewhat casual way in which these financial instruments were treated by the courts at the end of the last century will certainly not be perpetuated. Public interest in fulfillment of corporate obligations increases with each new issue. Financial interest that the corporate promise included in a public instrument shall be literally kept is fundamental. Only by strict performance will the faith of the investing public in such instruments be continued sufficiently to permit further investment as time goes on. We have been considering privileges which relate not to a static or definitive subject matter, but to shares of stock which are subject to change both in value and in kind, based on the corporate entity which is itself subject to change, involution or even disappearance. It is believed that the trend will be toward the evolution of equitable remedies tending to require the corporation to maintain itself in a position to meet the promises, whether of conversion or of option to purchase, as they fall due; and to prevent it from manipulating securities so as to deprive the privilege of its underlying value, or to cheat the investor in them of the chance for which he has bargained. 